International Journal of Advanced Academic Research (Social and Management Sciences) | ISSN: 2488-9849

\title{
DISTURBING TRENDS IN WORLD TRADE ORGANIZATION (WTO): MOBILIZING THE MEMBER NATIONS FOR THE RE-BUILDING PROCESS
}

\author{
Ebiziem, Jude Ebiziem Ph.D \\ Department of Political Science \\ Alvan Ikoku Federal College of Education, Owerri \\ E-mail: mbanoguesthouse@yahoo.com \\ 08035077757 \\ Amadi, Juliet Chidinma \\ Department of Public Administration \\ Federal Polytechnic, Nekede, Owerri \\ E-mail: amadichidinma3@gmail.com \\ $+2348063784202$ \\ Izim Okechukwu Declan \\ Department of Political Science \\ Alvan Ikoku Federal College of Education, Owerri \\ E-mail: okeyizim@ gmail.com \\ 08033182354 \\ Nwimo Kingsley Udochukwu \\ Human Resources Institute, Owerri \\ E-mail: nwimokingsley@gmail.com \\ 07068571116
}

\begin{abstract}
This study investigates the World Trade Organization (WTO), as a global and multi-lateral body that oversees the operations of the global trade. The objective is to examine the extent in which the World Trade Organization has operated and contributed smoothly, freely and optimally in building the economic growth of the member nations. Regrettably, the organization's inability to negotiate and resolve international trade issues has devastated the global trade mechanism, thus impacted negatively among the member nations. The study which its research design is descriptive survey, reviewed extant literature and adopted Globalization Theory as its theoretical framework. The data for the study was generated from documentary sources, while content analysis was applied in the analysis of data. Among the findings are the institutional challenges of leadership; poor consensus building, fragile trade disputes settlement structures, and weak enforcement tools mechanisms among others. Based on these, the study recommends fostering relations among member countries to rebuild trust, restoring consensus decision-making, and proactive institutional reforms, and integrated capacity building to strengthen efficiency and effectiveness in the service delivery of the organization.
\end{abstract}

Keywords: World Trade Organization (WTO), Consensus Building, Multi-lateral, Global Trade, Member Nations. 


\section{Introduction}

World Trade organization (WTO), is an organization created in 1995 during the Uruguay Round of General Agreement of Trade and Tarriff (GATT), to oversee and implement the reduction in tarriff and other non-tariff barrier that it negotiates on disputes arising over trade. In other words, it is an intergovernmental organization established to promote and regulate international trade. Historically, WTO which was formed in 1995 has had the following Director-Generals from European countries, vis: Ireland (1995), a carryover from (GATT), Italy (1995-1999), New Zealand (1999-2002), Thailand (20022005), France (2005-2013), and Brazil (2013-2020), respectively.

Structurally, it has over one hundred and sixty four (164) member-States and all major decisions, are made as a whole either by ministers, who meet at least once every two years or by other ambassador or delegates (who meet regularly in Geneva). Operationally, the three components of its administration mechanism include:

(a) An Executive apparatus, legislative and enforcement apparatus

(b) Senate, Judiciary and a Directorate

(c) A Trade Commission; a Dispute Settlement body and a council of ministers.

Technically, the basic structure of WTO agreement were centered on goods, services, intellectual, property, dispute and trade policy review. Importantly, WTO provides developing countries special status in an effort to spur their economic development which sometimes include exemption from trade provisions and special protection for the exports.

Apparently, the economic growth of the least developed member nation of the organization has not greatly improved by WTO multi-lateral and multi-dimensional activities. Rather, it is observed that most of the member nation had almost integrated themselves in the Regional Trade Agreement System (RTAs) to enable them access those facilities they were supposed to have from the World Trade Organization. Therefore, widening the focus and operational mechanism of WTO is pivotal for its stability and economic growth. Evidently, in an attempt to examine the disturbing trends in the organization of WTO, critical questions to guide the study were asked:

1. To what extent have the developing member nations benefit from WTO?

2. What is the level of trade negotiation and dispute resolution among the member nations?

3. What are the strategies of re-building WTO inadequacies to its member nations?

The above questions formed the fulcrum of this study.

Therefore, for easy understanding of the subject matter, this paper is organized as follows: Abstract, Introduction which gives the background of the study, Conceptual explication of the key terms including policy arguments in the Theoretical Framework, Methodology which delved into research design and sources of data collection and finally, the findings and conclusion. 


\section{Conceptual Explication}

\section{Understanding WTO}

World Trade Organization (WTO) is an organization globally designed to foster transparency, predictability and stability in Multilateral Trading System (MTS), monitor trade development, promote exchanges and build trust. The organization assists developing countries especially the least developed and small economies to boost trade through technical assistance and capacity building. Equally, the General Council of the organization concentrates its activities in the main area of trade in goods, trades in services, and the traderelated aspects of intellectual property (Kenan, 1995, and Ikegwuoha, 2019).

Again, the "Marrakesh Agreement" established the WTO from GATT framework, Articles XII discusses new accessions to the multilateral body World Trade Organization. Also, WTO secretariat created additional guidelines and a consistent set of procedures including:

(a) The establishment of a working party,

(b) Memorandum from the application country detailing its foreign regime,

(c) Negotiations both bilateral and multilateral as necessary on schedules of specific goods and services commitments.

(d) The working party's report on discussing, graft decision, and protocol of accession to be approved by existing members (World Trade Organization, 1995). Equally, while the guidelines call for a two-thirds majority of WTO members to approve of new member the unanimity rule that governs much of the WTO's activities perusal in practice, (Cattaneo and Primo Braga, 2009, Bernier and Schlandt, 2018).

However, the basic principles of World Trade Organization (WTO) include nondiscrimination; it has two major components the Most Favoured Nation (MFN) rule, and the National Treatment Policy.

- Reciprocity principle;

- Binding and enforcement commitment;

- Transparency; and

- Safety value

These basic principles were fully utilized in shaping the operational mechanism of the body with the member countries. Accordingly, the objectives of the world trade organization were stated as follows:

i) To set and enforce rules for internal trade

ii) To provide a forum for negotiating and monitoring further trade liberalization

iii) To resolve trade disputes

iv) To increase the transparency of decision making

v) To cooperate with other major international economic body.

Taking all together the most important features of World Trade Organization (WTO) is to seek to establish just and fair multilateral system of international trade where in the developed countries and the least developing countries, all have equal opportunities for market access for their products in foreign countries and wherein. 


\section{General Agreement on Tariff and trade (GATT)}

This is a legal agreement between many countries whose overall purpose was to promote internal trade by reducing or eliminating trade barriers as tariffs or quotas, (https://en.m.wikipedia.org.wiki).

Signed on 30 October, 1947, the workings of the GATT agreement are the responsibility of the council for trade in goods (Goods Council) which is made up of representative from WTO member countries. GATT during the (GATT) General Agreement on Tariffs and Trade) years, eight rounds of tariffs negotiation were held between 1947 and 1994; Geneva (1947), Annecy (1949), Torquay (1950 - 51), Geneva (1956), Geneva (1960 61) also known as the Billion Round. The Kennedy Round (1964 - 67), the Tokyo Round (1973 - 79) and Uruguay (1995).

In fact, The General Agreement on Tariff and Trade was created after World War II to aid global economic recovery through reconstructing and liberalizing global trade. The main objective was to reduce barriers to international trade through the reduction of tariff quotas and subsidies.

Basically, GATT main function is administering WTO trade agreements, producing a forum for trade negotiations, handling trade disputes, monitoring national trade policies, providing technical assistance and training for developing countries and ensuring cooperation with their international organizations. Although, WTO replaced GATT but the General Agreement still exists as WTO's umbrella treaty for trade in goods, updated as result Uruguay Round negotiations. GATT failure was itself only set of ranks and multilateral agreement and has no constituent bases. It has only interest in trade in goods without intellectual property rights.

\section{Methodology}

The necessary data required to examine this study were all sought from secondary sources. In this regard, conference papers, periodicals, internet materials, journals, newspapers, seminar papers, monographs, books, unpublished research works, documents and policy pronouncements constitute source of data and information for the study. These data were collated and studied for the work. Equally, rigorous method of content analysis was adopted in our analysis of the data. Kerlinger (1973:536) and Eme (1995:18) were of the view that content analysis is a research techniques for the objective, systematic and qualitative analysis.

The central objective of content analysis is to convert data or information into data which can be treated in a scientific manner so that a body of knowledge may be built up. The justification behind the use of content analysis of documents and other secondary data is that it allows research on areas where the researcher cannot have physical access to the respondents and thus, cannot by any other method. Therefore, content analysis was used in this study to examine the operations of World Trade Organization (WTO) and its impacts on member nation.

\section{Synthesis of the Literature on WTO}

Efforts to quantify the effect of GATT/WTO on member-countries have been based on the extant literatures that were extensively reviewed. Tormz etal (2007) found significant positive trade flow by including dejure and defacto membership. Subramanian and Wei (SW, 
2007) posited that many asymmetries relationship exist in WTO, Where positive trade flows were more pronounced with industrialized countries and liberalized manufactured products, not favourable for developing countries and agricultural products.

Arguably, Liu (2009) posited a significant positive trade effect of WTO membership countries. On their part, Herz and Wagnor (2011) assented that the level of effects of significant positive trade depends on negotiating period under consideration and techniques, methods employed in the process. However, Eicher and Henn (2011) put the trade facilitating impact of WTO squarely in doubt, as there is individual preferential trade agreement. These scholars found insignificant and sometimes negative trade flow effect of membership.

In otherwise, Tomz et al. (2007), Roy (2011) found a mixed impact on membership. Statistically positive, statistically negative and statistically dependent upon the decade being considered (Grant and Boys, 2015). Therefore, for significant justification, extant literature, were explored on the particular mechanisms through which WTO has impacted enhanced trade. Scholars examined the trade facilitation both in the intensive and extensive process.

However, as noted by Lui (2009), the establishment of new trading relationships may be due to the lower tariffs or more transparent trade policies afforded to trade between WTO members. Comprehensively, literature studies of Feenstra and Rose (1997), Wang and Winters (1992), Evenett and Venables (2002), Havenman and Hummels (2004), and Besede's and Prusa (2011) on intensive and extensive trade margins are indeed relevant to the work.

\section{Theoretical Framework}

\section{Globalization Theory}

Although, the discourse on theory in social sciences suffers from definitional crisis because of myriads of definitions on the concepts, however, a theory is lens through which we see the world (Obasi, 1999). It a set of empirically related generalization and a cause effect logical explanation of phenomenon and a prediction of its subsequent development, the highest level of generalization in a scientific discipline containing all the essential elements of explanation at particular stage of knowledge and embodying within the law, principles, and hypothesis that clarify issues at corresponding levels of analysis (Isaac in Obasi, 1999). To be exact, globalization theory according to (IMF, 1997) is a growing economic interdependence of countries worldwide through the increasing volume and variety of cross border transactions in goods and services and of international capital flows, and also through the more rapid and widespread diffusion of technology.

In other words, Globalization could be seen "here as the process of integration of the word into one huge market, that is removal of all trade barriers". Other background scholars on globalization such as David Held, Anthony Mcgrew, David Goldsath, and Jonathan perraton assert that globalization is the widening, deepening and speeding up of worldwide interconnectedness in all aspects of contemporary economic and social life, from the cultural to the criminal, the financial to the spiritual.

Equally, one of the outstanding definitions of globalization was given by UNDP National Human Development report of 2000/2001, as a "multidimensional process of unprecedented rapid and revolutionary growth in the extensiveness and intensity of interconnections on a truly global scale" (http//:www.unn.org). However, the main point to note in this view is that the economies of modern States have been highly integrated to the 
extent that the internationalization of trade and economic activities have become unavoidable and imperative global force.

Furthermore, some of the basic assumptions or tenets of the theory of globalization are:

i) Doing or planning to expand business and trade global.

ii) Giving up the distinction between the domestic market and foreign market and developing a global outlook of the business and commerce.

iii) Locating the production and other physical facilities on a consideration of global business dynamics, perspective of national considerations.

iv) Basing product development and production planning on the global market consideration.

v) Global sourcing of factors of production, that is, raw material components, machinery and technology finance to obtained from the best source anywhere in there world.

In fact, given the above assumptions, the identified economic benefits of the theory of globalization include expansion of trade, resource allocation widens the scope of resource generation, generation of growth multifiers and sustainable development framework (Chilaka, et al, 2019). Apparently, the theory has been criticized by author who have bemoaned it as harmful, lopsided, not equitable in its relationship with the developed and the developing nations. Indeed, it has been widely criticized as a tool of multinational corporations, as an institution that assaults national sovereignty and the enemy of the environment (Schott, 2000).

Further argument on disparity is focused on the bitter experience the developing countries being forced into giving trade and non-trade concessions to the developed countries at to a cost of their own interests. They realized that, with them, the developed countries want to have 'free trade'. The developed countries keep finding fresh "reason" for adding to the trade disadvantages of the developing countries; such 'reasons include, for example, adherence to labour standards (that is, non-use of child labour and low-wage labour), "physiosanitary conditions of product", among others.

\section{Application of the Theory}

According to Edozi, (1999:330) the world economy has been reduced to a global village market something almost akin to a village market with all its simple and fast business relationship. Equally Knor, (2001:1) posited that firms in the economically advanced countries have increasingly extended their outreach through trade and production activities (intensified in the colonial period). The focus of the theory is to erode all the national barriers that inhibit trade commerce investment financial relationship among member nations. This idea is to liberalize these areas being ending protectionalism with resultant effect of better cooperation and strengthen relationship for development. On the whole, the main justification of this theory on world trade organization is to limit or dismantle the barricades to free flow of relationship which has been promoted by the reduction of national barriers like transportation, communication cost, and artificial barrier such as tariffs, quotas, and exchange controls (Dwolabi, 1998:374).

\section{Obligations and Benefits of WTO to Members}

Many policy arguments by scholars and researchers have been raised on why would countries join the WTO and the accompanying benefits therefore. In fact, Plethora of 
assertions were advocated to include economic growth, trade market access and also dispute settlement among others. In this analysis, Bagwell and Staiger (2002) posited that WTO is shift to solve "terms-of-trade-driven prisoners' dilemma" among large countries under this prisoner's dilemma, large countries can through tariffs and non-tarriff barriers effect world prices in their favour through the protection they choose to implement, potentially increasing their own welfare at the expense of others (Bagwell and Staiger, 2002).

Furthermore, WTO creates a system based on the guiding principles of reciprocity and enforcement. These principles encourage trade, effectively locking in liberalization policies and low tariffs by removing a major incentive to the game system (Bagwell and Staiger 2000; Bernier and Schlandt, 2018). Furthermore, some of the main rights that members attain include improved market access of most Favoured-nation, (MFN) protection against adhoc protectionist measures from other members, a seat at the table of international trade rule making, and indeed access to the WTO's dispute settlement mechanism.

Additionally, the obligation of WTO members may also include efficient trade policies, lock in business reforms, signal a commitment to reform to other nations, demonstrate a desire for global cooperation. In fact, Evenett and Primo Braga (2005) refer to this signal as a "seal of approval that can help attract foreign investors. Most importantly, existing members have incentives for non-member countries to join the WTO, including export opportunities and market access protection for their investors to protectionist pressure abroad (Cattaneo and Prim Braga, 2009).

\section{Contending Challenges of WTO}

a) Global Disharmony: Apparently, the challenge in the multi-lateral trade negotiations had led to many member countries of the WTO in recent years to embark on plurilateral negotiation to advance particular issues. The disaffection has caused many member states to seriously engage themselves in Regional Trade Agreement (RTAs), to access to markets and tackle issues that are not sufficient addressed by WTO. This development has generated bitterness and acrimony among the member nations, the leadership, and conference of ministers in the organization.

b) Leadership Challenges: In fact, the failed progress of the Dohe Round of trade negotiations in establishing preferential trade agreement, has caused many to question the leadership capacity and relevance of WTO. The tool and mechanism in which the organization has potentially facilitated the trade had indeed exposed its weakness, ineptitude leadership in the operations of the body. It has been observed that lack of political will and dynamism in the leadership is a disturbing hurdle that must be terminated to move the organization forward.

c) Poor Consensus Building: Observably, lack of consensus building among the member nations has given the body a weak operational trade relationship technically, while World Trade Organization (WTO), stimulates the development of new and expanding trade relationships, Regional Trade Agreement System (RTAs) encourage greater specialization across existing product. This lack of trust is a hamstrung to the multilateral trade liberalization efforts of building a robust policy and stable world trade organization (WTO).

d) Digital Economy Divide: The problem of the digital divide in developing and least developed member nations poses a major impediment to the holistic successful operations of the organization. In fact, with the existence of the covid-19 pandemic, the digital 
economy are vital forms of trade especially in the poor member nations, where infrastructure facilities for e-commerce is relatively poor and unavailable; resulting to abysmal failure in trade negotiations.

\section{Strategies for the Re-Building Process in WTO}

Considering the challenges facing the operations and activities of World Trade Organization (WTO), the following critical solution oriented measures are imperative.

(i) Political Will: There is need to inject new political will in the administrative mechanism of the body. This political will play an essential role in the World Trade Organization (WTO) through mechanisms designed to foster transparency, predictability and stability in the trading system of (MTS). The application of the political will vigorously address and monitor trade developments, promote exchange and build trust among the member nations.

(ii) Trade Reform: Reinvigorating trade policy reforms will marginally assist the developing countries especially the least developed and small economies to boost trade through technical assistance and capacity building. Simply put, trade and trade policy have rightly become central to national development strategies. Indeed, WTO is needed to ensure that trade and global market remain open and are further expanded to encourage strong engagement and commitment from all WTO member nations. It is through this that the body can produce concrete result and better respond to the needs of the member at all levels of development. Furthermore, assisting proactively in Medium and Small Manufacturing Enterprises (MSMES) to produce and offer their product to consumers all around the world by linking trade of the world through basic common rules, thereby making WTO unique value added.

In fact, Regional Trade Agreement (RTAs) cannot substitute multilateral Trade System (MTS), because countries cannot solely rely on trade agreement with selected partners. Technology and other related innovation have reduced the impact of distance and the world is too connected. Rather, Regional Trade Agreement (RTAs) can compliment multilateral efforts (Evenet and Baraga, 2005).

(iii) To Create Synergies and Coordinate Support to Member Nation: The World Organization (WTO) should utilize the body to create synergies and coordinate support to alleviate the suffering of least developing nations in poverty, low economic growth and deficit trade relations. In fact, adopting an integrated approach of implementation, strengthening the agriculture sector, long term textile strategy, strengthening the institution for anti-dumping measures and competition policing and strengthen the legal expertise among others.

\section{Conclusion}

World Trade Organization (WTO) is a desideratum for global trade stability, liberalization and development. This could only be achieved if the organization can proactively reinvigorate with strategic reforms and to address critical quagmire and impediments like free trade benefits to developing countries, innovation on rules that undermine tariffs and restriction on agriculture adoption of consensus building to promote multilateral relationships, pragmatic leadership, anchored on political will and recognition of the cultural and social environment in international trade co-existence among the member- 
countries. Consequently, the onus for the re-building process lays with the levels of efficiency of the organization in championing dynamic and radical global trade policy.

\section{Recommendations}

(1) Introduction of innovative reforms that will take into cognizance of the dynamic socialcultural environment of trade operations among the member-countries.

(2) Recalibrate the laws establishing WTO to enable the body execute its functions effectively and efficiently.

(3) Using proactive leadership anchored on political will with a trajectory of a paradigm shift to restore trust and promote confidence building among the member-countries.

(4) To assiduously embark on implementation of trade policies that will enhance the economic growth of developing countries, thereby creating jobs, employments and tackling the issues of poverty globally.

(5) Equally, having a multilateral trading system that will provide a stable and transparent framework to help producers of goods and services, exporters and importers, to conduct business, thus, leads to more prosperous, peaceful, accountable economic world.

(6) Finally, adopting a holistic multilateral trade system that can incorporate policy dialogue, open plurilateralism, improvement of bureaucratic inputs and institutional performance aimed at strengthening cooperation and conflict resolution. 


\section{References}

Aaronso, S. and Abouharb, M. (2014). Does the WTO help Member States Improve Governance? World Trade Review, 13(3):547-582.

Bagwell, K. and Staiger, R. W. (2002). Economic Theory and the Interpretation of GATT/WTO. The American Economist, 4(2):3-19. Accessed from http://journals.sagepub.com/doi/pdf/10.1177/056943450204600201 on 20/07/2020.

Balding, C. 2010. "Joining the World Trade Organization: What is the Impact?", Review of International Economic, 18(1):193-206.

Bernard, Andrew, J. B. Jensen, S. Redding and P. Schott (2007). Firms in International Trade. Journal of Economic Perspective, 21:105-130

Besedes, T and Prusa, T. (2011). The Role of Extensive and Intensive margins and export growth. Journal of Development Economics, 96:371-379

Cattaneo, O. and Primo Braga, C. A. (2009). Everything you Always wanted to know about WTO Accession. World Bank Policy Research Working Paper, 5116.

Chang, P. L. and M. J. Lee. (2011). “The WTO Trade Effect”, Journal of International Economics, 85(1):53-71

Chemutai, V. and Escaith, H. (2017). An Empirical Assessment of the Economic Effects of WTO Accession and its Commitments. WTO Staff Working Paper, ERSD-2017-05. Accessed from http:// hdl.handle.net/10419/155702.

Choudhury, S. and Millimet, D. (2016). WTO Membership and Corruption. Accessed from https//faculty.smu.edu/millimet/pdf/WTOCorr.pdf on 20/07/2020.

Course.lumenlearning.com/wm-principlesof... Accessed from Wikipedia on 20/07/2020

Eicher, T. S. and C. Henn. (2011). "In Search of WTO Trade Effects: Preferential Trade Agreements Promote Trade Strongly, But Unevenly," Journal of International Economics, 83(2): 137-153.

Engelbrecht, B., and C. Pearce. 2007. "The GATT/WTO has Promoted Trade, but only in Capital-Intensive Commodities", Applied Economics, 39(12): 1573-1581.

En.wikipedia.org/wiki/WTO. Accessed from 08/07/2020.

Evenett, S. J. and Venables, A. J. (2002). Export Growth in Developing Countries: Market Entry and Bilateral Trade Flows. Mimeo. London School of Economics.

Evenett, S. J. and Primo Braga, C. A (2005). WTO Accession: Lessons from Experience. International Trade Department, World Bank Group. Accessed from http://siteresources.worldbank.org/INTRANETTRADE/Resources/Pubs/TradeNote2 2.pdf on 20/07/2020.5976. 
Feenstra, R., and Rose, A. K. (1997). Putting Things in Order: Patterns of Trade Dynamics and Macroeconomics. NBER Working Paper 5975. National Bureau of Economic Research, Cambridge, Mass

Feenstra, R., R. E. Lipsey, H. Deng, A. C. Ma, and H. Mo.( 2005). "World Trade Flows: 1962-2000”. NBER Working Paper No. 11040.

Grant, J. H. and K. A. Boys (2012). "Agricultural Trade and the GATT/WTO: Does Membership Make a Difference?" American Journal of Agricultural Economics, 94(1): 1-24.

Grant, J. H, (2013). Is the Growth of Regionalism as Significant as the headlines Suggest? Lessons from Agricultural Economics, 44(1):93-109.

Havenman, J. and Hummels, D. L. (2004). Alternative Hypothesis and the Volume of Trade: Evidence on the Extent of Specification. Canadian Journal of Economics, 37(1):199218.

Herz, B., Wagner, M. (2011). “The Real Impact of GATT/WTO-A Generalized Approach”, The World Economy, 34(1): 1014-1041.

https://wwwgoole.com/wto. Accessed on 25/07/2020

https://www.wto.org.Accessed on 25/07/2020.

Ikegwuoha, B. T. O. (2019). An Appraisal of International Politics, Law, Political Economy and World Order. Owerri: Ambix Publishers.

Kennan, I. P. (1995).Understanding interdependence: The Macro Economic of the Economy. Princeton University Press.

Kerlinger, F. N. (1973). Found of Behavioural Research. New York: Hott, Reinehart and Winston.

Khor, M. (2001). Globalization and the South Some Critical Issues. Ibadan: Spectrum Books

Liu, X, (2009). "GATT/WTO Promotes Trade Strongly: Sample Selection and Model Specification", Review of International Economics, 17(3):428-446.

Mbachu, O. I. (2016). Method of Data Analysis/Content Analysis in Social Science Research in Okolie, A. M. and Ajene, O. G (Eds). Research Method in Social Science Analysis. Published by Nigeria Political Science Association (NPSA) Ketti:c/o Nasarawa State University.

Obasi, I. N. (1999). Research Methodology in Political Science. Enugu: Academic Publishing Company.

Owolabi, E. A. (1985). Global and Scientific Co-operation in the Globalization Process. $C B N$ Economic and Financial Review. Dec (36)4

Rose, A. (2004). "Do we Really Know That WTO Increases Trade?" American Economic Review, 94(1): 8-114. 
Scott, J. J. (2002). The WTO After Seattle Washington D. C; Institute for International Economics.

Subramanian, A. and Wei, S. J. (2007). "The WTO Promotes Trade Strongly but Unevenly", Journal of International Economics, 72(1): 151-175.

Tomz, M. J. L., Goldstein, and Rivers, D. (2007). "Do We Really Know that WTO Increases Trade? Comment", American Economic Review, 97(5): 2005-2018.

Wag. Z. K. and Winters, A. (1992). The Trading Potential of Eastern Europe. Journal of Economic Integration, 7(2):113-136.

WTO (2007). World Trade Report (2007). Six Decades of Multilateral Trade Cooperation: What have we Learnt? WTO Document WT/REG/E/37,

www.amwericanexpress.com/us/foreign-exchange/. Accessed on 20/07/2020.

www.csis.org/analysis/value-wto. Accessed on 25/07/2020.

www.heritage.org/trade/report/the-wto-and-the. Accessed on 25/07/2020.

www.legalserviceindia.com/article/1320/Successes-and. Accessed on 08/07/2020

www.researchgate,net/publication/228236901. Accessed on 20/07/2020.

www.wto.org/english/thewto_e/whatis_e/whatis_e.htm. Accessed on 10/07/2020.

www.wto.org.english/thewto_e/whatis_e/tif_e/dev4. Accessed on 25/07/2020. 
APPENDIX

\section{MEMBER STATE OF WTO}

\begin{tabular}{|c|c|}
\hline Country & Year Join \\
\hline 1. Afghanistan & 29th July, 2016 \\
\hline 2. Albania & 8th September, 2000 \\
\hline 3. Angola & 23rd November, 1996 \\
\hline 4. Antigua and Barbuda & 1 January, 1995 \\
\hline 5. Argentina & 1 January, 1995 \\
\hline 6. Armenia & 5 January, 2003 \\
\hline 7. Australia & 1 January, 1995 \\
\hline 8. Austria & 1 January, 1995 \\
\hline 9. Bahrain, Kingdom of & 1 January, 1995 \\
\hline 10. Bangladesh & 1 January, 1995 \\
\hline 11. Barbados & 1 January, 1995 \\
\hline 12. Belgium & 1 January, 1995 \\
\hline 13. Belize & 1 January, 1995 \\
\hline 14. Benin & 22 February, 1996 \\
\hline 15. Bolivia, Plurinational State & 12 September, 1995 \\
\hline 16. Botswana & 31 May, 1995 \\
\hline 17. Brazil & 1 January, 1995 \\
\hline 18. Brunei Darusadam & 1 January, 1995 \\
\hline 19. Bulgaria & 1 December, 1996 \\
\hline 20. Burkina Faso & 3 June, 1995 \\
\hline 21. Burundi & 23rd July, 1995 \\
\hline 22. Cabo Verde & 23rd July, 2008 \\
\hline 23. Cambodia & 13th October, 2004 \\
\hline 24. Cameroon & 13th December, 1995 \\
\hline 25. Canada & 1 January, 1995 \\
\hline 26. Central Africa Republic & 31 May, 1995 \\
\hline 27. Chad & 19 October, 1996 \\
\hline 28. Chile & 1 January, 1995 \\
\hline 29. China & 11 December, 2008 \\
\hline 30. Columbia & 30 April, 1995 \\
\hline 31. Congo & 27 March, 1997 \\
\hline 32. Costa Rica & 1 January, 1995 \\
\hline 33. Cote d'Ivore & 1 January, 1995 \\
\hline 34. Croatia & 30 November, 2000 \\
\hline 35. Cuba & 20 April, 1995 \\
\hline 36. Cyprus & 30 July, 1995 \\
\hline 37. Czech Republic & 1 January, 1995 \\
\hline 38. Democratic Republic of Congo & 1 January, 1997 \\
\hline 39. Denmark & 1 January, 1995 \\
\hline 40. Djibouti & 31 May, 1995 \\
\hline
\end{tabular}




\section{Dominica}

42. Dominican Republican

43. Ecuador

44. Egypt

45. El Salvador

46. Estonia

47. Eswatini

48. European Union (formerly EC)

49. Fiji

50. Finland

51. France

52. Garbon

53. Gambia

54. Georgia

55. Germany

56. Ghana

57. Greece

58. Grenada

59. Guatemala

60. Guinea

61. Guinea-Bissau

62. Guyana

63. Haiti

64. Honduras

65. Hong Kong China

66. Hungary

67. Iceland

68. India

69. Indonesia

70. Ireland

71. Israel

72. Italy

73. Jamaica

74. Japan

75. Jardan

76. Kazakhstan

77. Kenya

78. Korea Republic of

79. Kuwait

80. Kyrgyz Republic

81. Lao People's Democratic Republic

82. Latvia

83. Lesotho

84. Liberia

85. Liechtenstein

86. Lithuania
1 January, 1995

9 March, 1995

21 January, 1996

30 June, 1995

7 May, 1995

13 November, 1999

1 January, 1995

1 January, 1995

14 January 1996

1 January, 1995

1 January, 1995

1 January, 1995

23 October, 1996

14 June, 2000

1 January, 1995

1 January, 1995

1 January, 1995

22 February, 1996

21 July, 1995

23 October, 1995

31 May, 1995

1 January, 1995

30 January, 1996

1 January, 1995

1 January, 1995

1 January, 1995

1 January, 1995

1 January, 1995

1 January, 1995

1 January, 1995

21 April, 1995

1 January, 1995

9 March, 1995

1 January, 1995

11 April, 2000

30 November, 2013

1 January, 1995

1 January, 1995

1 January, 1995

20 December, 1998

2 February, 2012

10 February, 1999

31 May, 1995

14 July, 2016

1 September, 1995

31 May, 2001 


\section{Luxembourg}

88. Macao, China

89. Madagascar

90. Malawe

91. Malaysia

92. Maladives

93. Mali

94. Malta

95. Mauritania

96. Mauritius

97. Mexico

98. Moldova Republic

99. Mongolia

100. Montenegro

101. Morocco

102. Mozambique

103. Myanmar

104. Nambia

105. Nepal

106. Netherlands

107. New Zealand

108. Nicaragua

109. Niger

110. Nigeria

111. North Macedonia

112. Norway

113. Oman

114. Pakistan

115. Panama

116. Papua New Guinea

117. Paraguay

118. Peru

119. Philippines

120. Poland

121. Portugal

122. Qatar

123. Romania

124. Russian Federation

125. Rwanda

126. Saint Kitts and Nevis

127. Saint Lucia

128. Saint Vincent \& the Grenadines

129. Samoa

130. Saudi Arabia

131. Senegal

132. Seychelles
1 January, 1995

1 January, 1995

17 November, 1995

31 May, 1995

1 January, 1995

31 May, 1995

31 May, 1995

1 January, 1995

31 May, 1995

1 January, 1995

1 January, 1995

26 July, 2001

29 January, 1997

29 April, 2012

1 January, 1995

16 August, 1995

1 January, 1995

1 January, 1995

23 April, 2004

1 January, 1995

1 January, 1995

3 September, 1995

13 December, 1996

1 January, 1995

4 April, 2003

1 January, 1995

9 November, 2000

1 January, 1995

6 September, 1992

9 June, 1996

1 January, 1995

1 January, 1995

1 January, 1995

1 July, 1995

1 January, 1995

13 January 1996

1 January, 1995

22 August, 2012

22 May, 1996

21 February, 1996

1 January, 1995

1 January, 1995

10 May, 2012

11 December, 2005

1 January, 1995

26 April, 2015 


\begin{tabular}{|c|c|}
\hline 133. Sierra Leone & 23 July, 1995 \\
\hline 134. Singapore & 1 January, 1995 \\
\hline 135. Slovak Republic & 1 January, 1995 \\
\hline 136. Slovenia & 30 July, 1995 \\
\hline 137. Solomon Islands & 26 July 1996 \\
\hline 138. South Africa & 1 January, 1995 \\
\hline 139. Spain & 1 January, 1995 \\
\hline 140. Sri Lanka & 1 January, 1995 \\
\hline 141. Suriname & 1 January, 1995 \\
\hline 142. Sweden & 1 January, 1995 \\
\hline 143. Switzerland & 1 July, 1995 \\
\hline 144. Chinese Taipei & 1 January, 2002 \\
\hline 145. Tajikistan & 2 March, 2013 \\
\hline 146. Tanzania & 1 January, 1995 \\
\hline 147. Thailand & 1 January, 1995 \\
\hline 148. Togo & 31 May, 1995 \\
\hline 149. Tonga & 27 July, 2007 \\
\hline 150. Trinidad \& Tobajo & 1 March, 1995 \\
\hline 151. Tunisia & 29 March, 1995 \\
\hline 152. Turkey & 26 March, 1995 \\
\hline 153. Uganda & 1 January, 1995 \\
\hline 154. Ukraine & 16 May, 2008 \\
\hline 155. United Arab Emirate & 10 April, 1996 \\
\hline 156. United Kingdom & 1 January, 1995 \\
\hline 157. United States & 1 January, 1995 \\
\hline 158. Uruguay & 1 January, 1995 \\
\hline 159. Vanuatu & 24 August, 2012 \\
\hline 160. Venezuela, Bolivarian Republic & 1 January, 1995 \\
\hline 161. Viet Nam & 11 January, 2007 \\
\hline 162. Yemen & 26 June, 2014 \\
\hline 163. Zambia & 1 January, 1995 \\
\hline 164. Zimbabwe & 5 March, 1995 \\
\hline
\end{tabular}

Source: (http://www.wto.org.English/thewto_e/gattmen_e.htm. Accessed on 20/07/2020) 